\title{
Bezpieczeństwo jako przedmiot nauczania w polskim systemie edukacji
}

\begin{abstract}
The paper presents the essence of the education for safety. There were analyzed both theoretical issues and curriculum of the education aimed at matters related to widely understood safety in the system of public education as well as system of education in the Ministry of the Interior and Administration.

Analysis of the theoretical aspects as well as of the practice proves that education for safety is successful. The society is educated in the necessary scope and therefore protected from a broad range of threats. Officers of the uniformed services are also educated in the scope sufficient for a professional fulfillment of the statutory duties. Such broad scope of safety knowledge allows the society to feel relatively secure. Such a sense of security is also contributed by the fact that this education continues to evolve and that main determinants of it are history, culture, traditions, geographical location, needs and challenges - so in fact potential threats, which in turn affects the process of education, attitudes, as well as the awareness.
\end{abstract}

\section{Keywords:}

safety, education, security science, department education

1 Jerzy Gąsiorowski, Katedra Bezpieczeństwa Narodowego i Zarządzania Kryzysowego, Wydział Nauk Stosowanych, Wyższa Szkoła Biznesu w Dąbrowie Górniczej, Polska, jerzy_gasiorowski@interia.pl. 


\section{WSTĘP}

System bezpieczeństwa państwa wymaga od jego organów oraz funkcjonariuszy i pracowników sfery bezpieczeństwa dogłębnej i merytorycznej wiedzy. Jest to spowodowane strukturą systemową bezpieczeństwa oraz różnego rodzaju zagrożeniami, w tym i przestępczością. Dla zapewnienia bezpieczeństwa niezbędna jest właściwa edukacja oraz permanentna prawno-organizacyjna analiza tego systemu. Jest to istotny element zarządzania bezpieczeństwem, bowiem brak edukacji w tym przedmiocie powoduje zmniejszenie aktywności podmiotów zajmujących się bezpieczeństwem, co w efekcie przyczynić się może do eskalacji zagrożeń i wystąpienia niepożadanych skutków.

Nauki o bezpieczeństwie są tym elementem w edukacji człowieka, który pozwala mu wpływać na bezpieczeństwo własne, jak i społeczeństwa. Wiedza ta jest niezbędna, bowiem sytuacje stwarzające zagrożenie dla człowieka i jego środowiska występują na co dzień, a przezorność i zapobiegliwość nie są najmocniejszą stroną społeczeństwa. Zatem nie jesteśmy często w stanie wystarczająco wcześnie dostrzec potencjalnych zagrożeń. Dlatego też dla właściwie rozumianego bezpieczeństwa istotne jest teoretyczne i praktyczne przygotowanie do rozpoznawania wszelkiego rodzaju zagrożeń i przeciwdziałania im. Przygotowanie to musi przybrać formę permanentnej edukacji dla bezpieczeństwa.

\section{BEZPIECZEŃSTWO JAKO PRZEDMIOT EDUKACJI}

Zapewnienie bezpieczeństwa państwu oraz obywatelom gwarantuje Konstytucja RP, która już w art. 5 zobowiązuje władze do podejmowania działań mających na celu ochronę niepodległości oraz nienaruszalności terytorium, ale także ochrony swoich obywateli ${ }^{2}$. Ochrona tych dóbr, tak w aspekcie prawnym, organizacyjnym oraz instytucjonalnym wymaga od władz państwowych stworzenia i funkcjonowania systemu bezpieczeństwa, obejmującego „celowo stworzony całokształt norm prawnych, organów ustawodawczych i wykonawczych, a także środków, metod działalności ukierunkowanej na zapewnienie niezawodnego systemu bezpieczeństwa” (Głukowski, 2007, s. 35). Jednym z bardzo istotnych elementów tego systemu jest edukacja dla bezpieczeństwa pozwalająca przewidywać niebezpieczeństwa, stosować działania zapobiegawcze i umiejętnie reagować w sytuacjach

2 Ustawa z 2 kwietnia 1997 r. Konstytucja Rzeczypospolitej Polskiej (Dz.U. Nr 78 poz. 483 z późn. zm.). 
zagrożeń. Nauki o bezpieczeństwie ${ }^{3}$ są zatem tym elementem w edukacji każdego człowieka, który pozwala mu wpływać na bezpieczeństwo własne i środowiska, jak i społeczeństwa. Wiedza ta jest niezbędna, gdyż sytuacje stwarzające zagrożenie dla człowieka występują (i występować będą) na co dzień, często w najbliższym otoczeniu, charakteryzują się zróżnicowanym potencjałem i zakresem, a wraz ze zmianami cywilizacyjnymi może dochodzić do ich eskalacji.

Różnymi aspektami bezpieczeństwa zajmują się przedstawiciele odpowiednich dyscyplin naukowych, a w aspekcie praktycznym podmioty instytucjonalnie i komercyjnie zajmujące się zapewnieniem bezpieczeństwa. Wprawdzie każda kategoria bezpieczeństwa jest ważna, to szczególne miejsce w tym systemie zajmuje bezpieczeństwo wewnętrzne. Dlatego też istotne jest wszechstronne przygotowanie społeczeństwa do przeciwdziałania wszelkiego rodzaju zagrożeniom. Przybrać ono powinno formę permanentnej edukacji dla bezpieczeństwa, a więc dydaktyczno-wychowawczej działalności rodziny, szkoły, środków masowego przekazu, organizacji społecznych i stowarzyszeń oraz formacji odpowiedzialnych za bezpieczeństwo, tj. Policji, Sił Zbrojnych itp., która służy upowszechnianiu idei, wartości oraz wiedzy i umiejętności istotnych dla zachowania zewnętrznego i wewnętrznego bezpieczeństwa państwa.

\section{SYSTEM EDUKACJI DLA BEZPIECZEŃSTWA}

W naukach społecznych bezpieczeństwo ma charakter podmiotowy i przedmiotowy. Poszczególnymi aspektami przedmiotowo rozumianego bezpieczeństwa (np. militarne, ekologiczne, zdrowotne, ekonomiczne, informatyczne czy publiczne) zajmują się przedstawiciele odpowiednich dyscyplin naukowych, jak i - w aspekcie praktycznym - podmioty instytucjonalnie i komercyjnie zajmujące się zapewnieniem bezpieczństwa w poszczególnych kategoriach. Choć każda kategoria bezpieczeństwa jest tak dla państwa, jak i obywatela ważna, to jak się wydaje, szczególne znaczenie należy przypisać bezpieczeństwu wewnętrznemu, a w jego

3 Nauki o bezpieczeństwie jako dyscyplina naukowa zostały zarejestrowane w dziedzinie nauk humanistycznych na początku 2011 roku, a następnie w nowo wyodrębnionym obszarze i nowo wyodrębnionej dziedzinie nauk społecznych, obok nauk o obronności, nauk o mediach, nauk o polityce, nauk o polityce publicznej, nauk o poznaniu i komunikacji społecznej, pedagogiki, psychologii i socjologii. Nauki o bezpieczeństwie - jako dyscyplina naukowa wchodząca w skład obszaru nauk społecznych i dziedziny nauk społecznych, utworzona została uchwałą Centralnej Komisji do Spraw Stopni i Tytułów z 28.01.2011 r. zmieniającą uchwałę w sprawie określenia dziedzin nauki i dziedzin sztuki oraz dyscyplin naukowych i artystycznych (M.P. z 2011 r., Nr 14 poz. 149). 
ramach - bezpieczeństwa i porządku publicznego (Gąsiorowski, 2013, s. 101 i nast.). Kształtując zatem środowisko bezpieczeństwa personalnego i strukturalnego, realizuje się to w ramach procesu edukacji, a więc świadomego i planowego działania, którego celem jest wpływanie na postawy, wartości i wiedzę oraz umiejętności konieczne do przeciwdziałania zagrożeniom i zapobiegania, niewelowania i usuwania ich skutków. Tak zakreślony proces edukacji dla bezpieczeństwa, w praktyce i doktrynie określany z łaciny „securitologią”4, ma ustawowo określone ramy programowe $\mathrm{w}$ postaci systemu edukacji ${ }^{5}$, przygotowującego obywateli do życia w społeczeństwie, dające im niezbędną wiedzę i umiejętności do radzenia sobie w życiu codziennym oraz właściwego współżycia z innymi, a także możliwości pokonywania mniej lub bardziej złożonych trudności poruszania się w labiryncie administracji itd. Zatem w ramach zapobiegania zagrożeniom najlepszym rozwiązaniem zdaje się szeroko rozumiana edukacja dla bezpieczeństwa, a więc w aspekcie militarnym, niemilitarnym, jak i bezpieczeństwa i porządku publicznego, a zatem kształcenie funkcjonariuszy instytucjonalnych służb porządkowych (w tym specjalnych) i formacji samorządowych, które spełniają fundamentalną rolę w systemie bezpieczeństwa oraz całego społeczeństwa (Gąsiorowski, 2014, s. 329 i nast.).

\section{A. SYSTEM SZKOLENIA FUNKCJONARIUSZY POLICJI I INNYCH SŁUŻB MUNDUROWYCH}

Jednym z elementów „edukacji dla bezpieczeństwa” jest kształcenie funkcjonariuszy policji i służb specjalnych. Obowiązek ten wynika z ustaw szczególnych i dotyczy wszystkich podmiotów (tzw. służb mundurowych) zobowiązanych do ochrony bezpieczeństwa oraz porządku publicznego. Tak więc każda tego typu formacja w tym przedmiocie realizuje szkolenie swoich funkcjonariuszy w specjalnych ośrodkach szkolenia, najczęściej - ze zrozumiałych względów - niedostępnych dla osób niebędących funkcjopnariuszami tych służb.

Biorąc pod uwagę, że w systemie bezpieczeństwa wewnętrznego najistotniejszą rolę spełnia policja, która jest „umundurowaną i uzbrojoną formacją służącą społeczeństwu i przeznaczoną do ochrony bezpieczeństwa ludzi oraz do utrzymywania

4 „Securitologia”, należąc do nauk praktycznych, „w sposób naukowy wskazuje perspektywę niwelowania zagrożeń dla istnienia, rozwoju i normalnego funkcjonowania człowieka, organizacji społecznych i instytucji państwowych, jak i samego Państwa” (Korzeniowski, 2012, s. 73).

5 Patrz: Ustawa z 7 września 1991 r. o systemie oświaty (Dz.U. z 2004 r. Nr 256 poz. 2572); Ustawa z 27 lipca 2005 r. Prawo o szkolnictwie wyższym (Dz.U. z 2012 r. poz. 572 z późn. zm.) i szereg aktów wykonawczych. 
bezpieczeństwa i porządku publicznego”, aby w sposób właściwy wykonać nałożone zadania, odpowiednio szkoli się jej funkcjonariuszy. W systemie szkolnictwa policyjnego obowiązują trzy rodzaje kształcenia zawodowego:

- centralne [organizowane przez Wyższą Szkołę Policji w Szczytnie (WSPol.) oraz szkoły policyjne i ośrodki szkolenia] w formie kursów specjalistycznych, których programy wprowadzane są do użytku służbowego decyzjami Komendanta Głównego Policji, jak również - spełniające w aspekcie edukacyjnym równie istotne zadania - jednostki badawczo-rozwojowe (np. Cenralne Laboratorium Kryminalistyczne - Instytut Badawczy z siedzibą w Warszawie);

- lokalne (organizowane przez jednostki i komórki organizacyjne policji), co daje swobodę kształtowania rodzaju przedsięwzięć i ich treści programowych, w zależności od zidentyfikowanych w tym zakresie potrzeb;

- zewnętrzne (organizowane przez podmioty pozapolicyjne), na które kieruje się policjantów wtedy, gdy zidentyfikowanych potrzeb szkoleniowych nie można zaspokoić w ramach doskonalenia centralnego lub lokalnego (Letkiewicz, Szankin, 2013, s. 247-248).

Przedmiot i zadania dydaktyki policyjnej są w pełni zbieżne z dydaktyką cywilną - różni się jedynie podmiot oddziaływań, którym jest w tym przypadku policjant na poszczególnych szczeblach swojej kariery zawodowej.

Podstawową rolę w szkolnictwie policyjnym odgrywa Wyższa Szkoła Policji powołana na mocy rozporządzenia Rady Ministrów z 10 września 1990 r. ${ }^{7}$ Uczelnia działa zgodnie z ustawą z 27 września 2005 r. Prawo o szkolnictwie wyższym i jest uczelnią służb państwowych nadzorowaną przez MSWiA. Uczelnia ta prowadzi studia pierwszego stopnia na kierunku administracja, a także pierwszego i drugiego stopnia na kierunku bezpieczeństwo wewnętrzne oraz studia podyplomowe i kursy dokształcające. Realizuje również szkolenia i doskonalenie zawodowe dla funkcjonariuszy policji oraz innych służb podległych MSWiA, a także innych podmiotów realizujących zadania w zakresie bezpieczeństwa i porządku publicznego.

Oprócz WSPol. system szkolnictwa policyjnego tworzą także: Centrum Szkolenia Policji w Legionowie (CSP), Szkoła Policji w Słupsku, Szkoła Policji w Pile, Szkoła Policji w Katowicach, szkolące funkcjonariuszy na kursach podstawowych i specjalistycznych, oraz terenowe ośrodki szkolenia przygotowujące policjanta do służby na podstawowym stanowisku pracy.

6 Art. 1 ust. 1 ustawy z 06 kwietnia 1990 r. o Policji (Dz.U. z 2015 r. poz. 355 z późn. zm.).

7 Rozporządzenie Rady Ministrów z 10 września 1990 r. w sprawie utworzenia Wyższej Szkoły Policji oraz zniesienia Akademii Spraw Wewnętrznych (Dz.U. Nr 64 poz. 373). 
Tak ukształtowany system szkolnictwa policyjnego wspomaga utworzona w 1993 roku w Wiedniu (przez MSW Austrii, Polski, Czech, Słowacji, Węgier i Słowenii) Środkowoeuropejska Akademia Policyjna wspierająca transgraniczną i międzynarodową współpracę policyjną poprzez organizowanie szkoleń i kursów dla policjantów z państw sygnatariuszy (językiem wykładowym Akademii jest język niemiecki) i powołane w 1998 roku w ramach organizacyjnych CSP w Legionowie Międzynarodowe Centrum Szkoleń Specjalistycznych Policji.

Wymienione instytucje edukacyjne prowadzą szkolenie i doskonalenie personelu w celu „uzupełniania przez pracowników wiedzy niezbędnej do prawidłowego wykonywania zadań na aktualnym stanowisku pracy oraz stworzenie możliwości dodatkowego rozwoju wiedzy, umiejętności i kompetencji pod kątem awansu, przesunięcia lub zmiany organizacyjnej” (Letkiewicz, 2009, s. 43). Szkolenia te umożliwiają poszerzanie horyzontów funkcjonariuszy i rozwijają cechy osobowości, które sprzyjają innowacyjności i przedsiębiorczości w tak szczególnym zawodzie oraz zaspokajają potrzeby samorealizacji. Ponadto funkcjonariuszy policji (i innych służb mundurowych), bez względu na zajmowane stanowisko, posiadany stopień policyjny, wykształcenie lub poziom ukończonego szkolenia zawodowego dodatkowo obejmuje się realizowanym w jednostkach terenowych doskonaleniem zawodowym, którego celem jest:

- wyposażenie w wiedzę i umiejętności zawodowe w związku ze zmianami w systemie prawa, a także technice i wyposażeniu policyjnym, taktyce i technice działania, metodach kierowania, dowodzenia i organizacji pracy oraz zmianami w tendencjach rozwojowych przestępczości albo też niezbędne do wykonywania specjalistycznych zadań i czynności;

- uzupełnienie wiedzy i umiejętności zawodowych w obszarach, w których stwierdzono braki;

- utrwalenie wiedzy i umiejętności zawodowych oraz ich sprawdzenie w określonych przedziałach czasowych;

- utrzymanie oraz podniesienie sprawności fizycznej oraz strzeleckiej (Michalak, 2005, s. 7).

Tak szeroki zakres szkolenia i doskonalenia zawodowego funkcjonariuszy policji wynika z tego, że muszą oni posiadać wiedzę ogólnopolicyjną o bardzo szerokim spektrum. Dotyczy ona m.in. zagadnień związanych z prawem karnym i procesowym (i prawem wykroczeń i w sprawach o wykroczenia), z kryminalistyką i przestępczością oraz innymi zjawiskami zagrażającymi bezpieczeństwu publicznemu, jak też z uregulowaniami prawnymi dotyczącymi sposobów i zasad funkcjonowania policji jako instytucji. Funkcjonariusze zdobywają także umiejętności, których wykształcenie i doskonalanie jest niezbędne do wykonywania 
tego zawodu, a więc umiejętności specjalistyczne, niezbędne do skutecznego zapewnienia bezpieczeństwa i porządku publicznego, oraz umiejętności uniwersalne, dotyczące znajomości podstawowych praw determinujących zachowania człowieka i stosowania ich podczas wykonywanych zadań.

Inne służby mundurowe również mają własny system edykacjii, jak np.:

- Państwowa Straż Pożarna - szkoli przyszłych strażaków oraz doskonalących swoje umiejętności funkcjonariuszy w Szkole Głównej Służby Pożarniczej w Warszawie, w Szkole Aspirantów PSP w Poznaniu, Szkole Aspirantów Państwowej Straży Pożarnej w Krakowie, w Centralnej Szkole PSP w Częstochowie, Szkole Podoficerskiej PSP w Bydgoszczy oraz w jednostce naukowej Szkoły Głównej Służby Pożarniczej - Zakładzie Informatyki i Łączności SGSP;

- Straż Graniczna - swoje kadry szkoli m.in. w Centralnym Ośrodku Szkolenia Straży Granicznej w Koszalinie oraz Centrum Szkolenia Straży Granicznej w Kętrzynie;

- służby specjalne - pracowników szkoli się np. w Centralnym Ośrodku Szkolenia Agencji Bezpieczeństwa Wewnętrznego w Emowie a Agencji Wywiadu - w Ośrodku Szkolenia Agencji Wywiadu w Starych Kiejkutach;

- straże gminne/miejskie ${ }^{8}$ itd.;

- komercyjne podmioty ochrony osób i mienia, przy czym system edykacyjny poszczególnych służb odpowiada potrzebom wynikającym z ich specyfiki zawodowej.

\section{B. SYSTEM POWSZECHNEJ EDUKACJI DLA BEZPIECZEŃSTWA}

Współczesny proces edukacji w sposób świadomy i planowy wpływa na postawy, system wartości, wiadomości i umiejętności konieczne do zapobiegania skutkom zagrożeń, ich niewelowania i usuwania, dlatego też ramy programowe obowiązującego w Polsce systemu edukacji zawierają niezbędne treści przygotowujące przede wszystkim młodego człowieka do życia w społeczeństwie. Aby jednak skutecznie zapobiegać i minimalizować zagrożenia, najlepszym rozwiązaniem jest edukacja dla bezpieczeństwa całego społeczeństwa, a nie tylko młodzieży podlegającej edukacji szkolnej.

Obejmując edukacją dla bezpieczeństwa szeroki zakres społeczeństwa, w ramach kształcenia realizuje się wszechstronne przygotowanie do życia w społe-

8 Rozporządzenie Ministra Spraw Wewnętrznych i Administracji z 17 grudnia 2009 r. w sprawie szkolenia podstawowego strażników gminnych (miejskich) (Dz.U. z 2013 r. poz. 353). 
czeństwie oraz zdobywanie umiejętności, dzięki którym można zapewnić bezpieczeństwo sobie i otoczeniu, bez względu na wiek i doświadczenie życiowe. Jest to zrozumiałe, gdyż aby żyć bezpiecznie, należy przestrzegać zasad, które odnoszą się do przewidywania niebezpieczeństw, stosowania działań zapobiegawczych, bycia w gotowości na wyzwania oraz umiejętności reagowania w sytuacjach zagrożeń. Niezbędna jest zatem merytoryczna wiedza oraz znajomość własnej psychiki i możliwości fizycznych, gdyż człowiek w krytycznych sytuacjach zdolny jest do pokonania strachu i uruchomienia dodatkowych zasobów energii, a zatem znając potencjalne źródła zagrożeń i sposoby ich unikania, jesteśmy w stanie im sprostać, a świadomość tego daje poczucie bezpieczeństwa. Aby je zwiększyć, należy we właściwy sposób edukować społeczeństwo, w większym zakresie realizować różne projekty w każdym z pożądanych społecznie nurtów, prądów czy normatywnych projektów, jak i zwiększać zaangażowanie w samoświadomości ludzi, którzy są przecież narażeni na manipulację, wykorzystanie czy ekskluzję. Istotne zatem jest uświadomienie społeczeństwu, że nie należy przeceniać własnych umiejętności w przedmiotowym zakresie, bowiem zbytnia pewność siebie, brawura, bezmyślność i nierozwaga mogą przynieść negatywne w skutkach konsekwencje.

Jak słusznie podkreślają J. Kunikowski i P. Szmitkowski (2011, s. 73), zagrożenia jako zjawiska nieporządane i niespodziewane mają charakter obiektywny, natomiast ich uświadomienie oraz wiedza i praktyczne postępowanie, by im przeciwdziałać - charakter subiektywny, dlatego też we współczesnych uwarunkowaniach edukacyjnych istotne jest jak najszersze uświadomienie społeczeństwu zagrożeń oraz popularyzowanie wiedzy obronnej w ramach edukacji dla bezpieczeństwa, jak też umiejętność praktycznego postępowania w warunkach ich występowania. Zaznaczyć jednak należy, że edukacja dla bezpieczeństwa w społeczeństwie jest uwarunkowana wieloma innymi czynnikami, jak układ stosunków społeczno-ekonomicznych, polityka ogólna i obronna, polityka edukacyjna państwa i podmiotów niepaństwowych oraz potrzeby i aspiracje życiowe jednostek (Dębowiak, 2013, s. 317).

Powyższe czynniki kształtują edukację dla bezpieczeństwa, nie mniej jednak istotny wpływ na ten kształt mają także przedstawiciele doktryny oraz praktycy na co dzień zajmujący się problematyką bezpieczeństwa i szeroko, nie tylko militarnie, rozumianej obronności, którzy coraz wyraźniej uświadamiają sobie, że fenomeny psychospołeczne i prakseologiczne, traktowane jako przedmiot badań, mają i muszą mieć charakter inter- i transdyscyplinarny (Cieślarczyk, 2011, s. 29). W związku z tym opisywanie, wyjaśnianie, ocenianie i przewidywanie zdarzeń (faktów), procesów i zjawisk w sferze bezpieczeństwa, ale także projektowanie struktur i podejmowanie działań służących zapewnieniu bezpieczeństwa wymagają 
wykorzystania zintegrowanej w sposób systemowy wiedzy z różnych dziedzin i dyscyplin naukowych, przede wszystkim z obszaru nauk humanistycznych i społecznych, nauk przyrodniczych, ścisłych i technicznych. Korzystanie z tak różnych dziedzin i dyscyplin naukowych w procesie edukacji dla bezpieczeństwa jest niezbędne - w odpowiednim oczywiście zakresie, dostosowanym do poziomu kształcenia - na poziomie szkoły podstawowej, gimnazjum oraz w szkołach ponadgimnazjalnych, z uczelniami wyższymi włącznie.

Tak ukierunkowane kształcenie dzieci i młodzieży pozwala zrozumieć współczesny świat, a zatem kształtować ich świadomość, która w przyszłości będzie przynosić efekty. Choć takie podejście wydaje się oczywiste, to w praktyce występuje szereg trudności w zakresie programowym. Konstruując ten proces, winno się brać pod uwagę związek rozwoju nauk z praktyką wychowania, gdzie wyróżnia się szereg funkcji nauk społecznych (diagnostyczna, prognostyczna, instrumentalno-techniczna i humanistyczna), które nie ograniczają się do gromadzenia wiedzy, ale ukazują jej ustawiczne systematyzowanie, doskonalenie, pozwalające osiągnąć zamierzone cele i potrzeby indywidualne oraz społeczne. Aby spełnić te wymagania, proces edukacji dla bezpieczeństwa winien uwzględniać zasadnicze zadania pedagogiki, a mianowicie:

- gromadzenie wiedzy o rzeczywistości wychowawczej i opis wyników tej obserwacji (przebiegu procesów wychowawczych);

- uogólnienie zebranych wyników obserwacji, wykrywanie związków i zależności między zjawiskami wychowawczymi oraz formułowanie wniosków (co do prawidłowości przebiegu procesów wychowawczych), wyjaśnienie tych związków i zależności w celu ukazania, które z nich wywołują pożądane zjawiska wychowawcze, a które niepożądane z punktu widzenia prawidłowości rozwoju osobowości człowieka, a także w celu umożliwienia przewidywania przebiegu tego rozwoju i kierowania nim;

- dostarczanie wiedzy potrzebnej do przekształcenia rzeczywistości wychowawczej; ustalenie celów i zasad wychowania w funkcjonowaniu w związku z rozwojem społeczno-ekonomicznym społeczeństwa; wytyczanie metod realizacji celów wychowania; sprawdzanie skuteczności tych metod w praktyce; wskazywanie możliwości i sposobów rozwiązywania problemów wychowawczych w konkretnych środowiskach wychowawczych i w odniesieniu do konkretnej sytuacji życiowej człowieka; opracowywanie głównych założeń organizacji pracy wychowawczej i dydaktycznej w celu zapewnienia optymalnej efektywności wysiłków zmierzających do osiągnięcia określonych zmian osobowości człowieka; konstruowanie modelu osobowości człowieka przyszłości przy uwzględnieniu tendencji 
rozwojowych nauki, techniki i kultury; formułowanie wzoru osobowości nauczyciela-wychowawcy na podstawie analizy celów wychowawczych i wiedzy empirycznej o jego roli i działaniu w procesie wychowania (Kunikowski, 2011, s. 12-14).

Biorąc powyższe uwarunkowania procesu edukacji dla bezpieczeństwa pod uwagę, wraz z wprowadzeniem w 1999 roku reformy oświaty dostosowano treściowo i metodycznie strukturę systemu szkolnego we wszystkich typach szkół, a więc placówkach wychowania przedszkolnego, szkołach podstawowych sześcioklasowych, trzyletnich gimnazjach, trzyletnich liceach ogólnokształcących, czteroletnich technikach, trzyletnich liceach profilowanych, dwuletnich szkołach zawodowych, szkołach policealnych oraz liceach uzupełniających. Ta struktura podziału systemu szkolnego, jak się wydaje, jest w stanie w sposób właściwy, dostosowany do rozwoju intelektualnego dzieci i młodzierzy, uświadomić im występujące zagrożenia oraz popularyzować wiedzę obronną, a także nabywać i kształtować umiejętności praktycznego postępowania w warunkach ich występowania.

W szkołach podstawowych edukację obronną rozpoczyna się zgodnie z programem nauczania dla szkół podstawowych lekturą pozycji Elementy ratownictwa i obrony cywilnej ${ }^{9}$. Celem kształcenia i wychowania na tym etapie jest wspomaganie wszechstronnego i harmonijnego rozwoju ucznia poprzez wyrobienie umiejętności działania w różnych sytuacjach szkolnych i pozaszkolnych, takich jak nabywanie umiejętności niezbędnych do udzielenia pierwszej pomocy, przygotowanie się do zachowań bezpiecznych na drodze, w czasie gier i zabaw, ostrożne posługiwanie się niebezpiecznymi narzędziami (np. nożem, nożyczkami, zapałkami itd.), nabycie umiejętności wzywania pogotowia ratunkowego oraz wykształcenie w sobie gotowości niesienia pomocy poszkodowanym. W drugim etapie uczniowie nabywają zachowania sprzyjające bezpieczeństwu ludzi i przyrody oraz zdrowiu i bezpieczeństwu, zachowania się w przypadku kontaktu z przedmiotami niebezpiecznymi, toksycznymi, łatwopalnymi, wybuchowymi, niewybuchami czy niewypałami oraz umiejętność niesienia pierwszej pomocy w niektórych urazach oraz gotowość niesienia pomocy poszkodowanym. Kładzie się tu duży nacisk na wyrobienie praktycznych umiejętności radzenia sobie w sytuacjach kryzysowych, ale także na edukację patriotyczno-obywatelską. Efektem tak prowadzonego procesu kształcenia powinno być:

9 Program zatwierdzony do użytku szkolnego przez MEN 15 marca 1999 r., decyzja nr DKW $-4014-30 / 99$. 
wpojenie uczniom umiejętności i postaw w zakresie rozpoznawania bezpośredniego zagrożenia zdrowia i życia ludzkiego, ratownictwa w nagłych stanach zagrożenia życia i wypadkach, samopomocy i udzielania pierwszej pomocy przedmedycznej poszkodowanym, posługiwania się improwizowanymi i etatowymi środkami, sprzętem ratowniczym oraz środkami zastępczymi, posługiwania się podręcznymi środkami przeciwpożarowymi, organizowania pomocy, alarmowania o zagrożeniu i wzywania pomocy zawodowej, zachowania się podczas ewakuacji z terenu zagrożonego, posługiwania się wybranymi przyrządami rozpoznawania skażeń i środkami ochrony przed skażeniami (Wierzbicki, 2011, s. 55-56).

Na etapie szkoły gimnazjalnej edukacja obronna jest realizowana według programu nauczania „Ścieżka Edukacyjna Obrona Cywilna”10, która wspólnie ze ścieszkami edukacyji ekologicznej i prozdrowotnej zakłada realizację elementów wiedzy obronnej na poszczególnych przedmiotach nauczania, w ramach których uczniowie zdobywają wszechstronną wiedzę, przygotowującą ich do radzenia sobie w sytuacjach zagrożenia. Na tym poziomie kształtuje się także postawy bezpiecznego i świadomego zachowania się w każdej sytuacji, gotowości udzielenia pomocy innym oraz poszanowania i respektowania prawa. Edukacja ta zawiera także tzw. ścieżki międzyprzedmiotowe, a więc edukację europejską i regionalną (dziedzictwo kulturowe w regionie), które wnoszą istotny wkład w kształtowanie postaw patriotycznych młodzieży.

W szkołach ponadgimnazjalnych kształcenie w zakresie edukacji dla bezpieczeństwa ma charakter długofalowy. Cele sformułowane są ogólnikowo i łączą elementy poznawcze i wychowawcze obejmujące przyswojenie przez uczniów określonego zasobu wiadomości na temat faktów, zasad, teorii i praktyk, a także zdobycia przez uczniów umiejętności wykorzystania posiadanych wiadomości podczas wykonywania zadań i rozwiązywania problemów, jak też kształtowanie wśród uczniów postaw warunkujących sprawne i odpowiedzialne funkcjonowanie we współczesnym świecie. Wiedza ta kształtuje i wzmacnia postawę społeczną i obywatelską uczniów, odczuwanie więzi ze wspólnotą lokalną, narodową, wpaja szacunek dla zasad państwa demokratycznego, a zatem poszanowanie prawa i respektowania zasad obowiązujących w Polsce. Wykształca także wśród uczniów postawy obywatelskie, jak np. zaangażowanie w kampanie, programy, akcje inicjowane przez instytucje i organizacje pozarządowe.

10 Program zatwierdzony do użytku szkolnego przez MEN 15 marca 1999 r., decyzja nr DKW - 4014-121/99. 
Reasumując, w oparciu o analizę programów nauczania na etapie szkoły gimnazjalnej i ponadgimnazjalnej powinno się zwiększyć zakres wiedzy o aspekty prawne (przestępstwa, wykroczenia i czyny zabronione popełniane przez osoby nieletnie). Jest to o tyle zasadne, że z przestępczością (i patologią) mamy do czynienia na co dzień, a zatem szerszy zakres wiedzy w tym przedmiocie w wielu przypadkach pozwoliłby uniknąć konfliktów z prawem, jak i zapobiegać przestępczości (funkcja prewencyjna).

Przykładem tego typu edukacji w strukturze edukacji dla bezpieczeństwa jest specjalistyczna edukacja w tzw. klasach mundurowych, która poza nauczaniem ogólnokształcącym z przygotowaniem do matury przygotowuje uczniów do pracy w służbach mundurowych. W tym celu uczniowie zobowiązani są do przestrzegania dodatkowego regulaminu klas mundurowych (np. obowiązek noszenia munduru) oraz przyswojenia sobie podstaw wiedzy o służbach mundurowych (zajęcia prowadzone przez czynnych wojskowych w klasach wojskowych i policjantów w klasach policyjnych) i samoobrony. Każdy uczeń bierze udział w przynajmniej jednym poligonie (letnim i/lub zimowym), zajęciach na strzelnicy sportowej (szkolenie w posługiwaniu się bronią długą i krótką pod opieką instruktorów), ma także możliwość udziału w zajęciach terenowych, gdzie uczy się korzystania z kompasu i mapy topograficznej (zajęcia te mają na celu wyćwiczenie umiejętności orientacji w terenie oraz zapoznanie się z elementami terenoznawstwa), a w ramach wychowania fizycznego ma możliwość wzięcia udziału w biegach na orientację, zawodach survivalowych (włącznie z udziałem w obozach survivalowych) oraz w ramach współpracy - wizytować jednostki różnych służb mundurowych (policji, wojska itd.).

Edukacja dla bezpieczeństwa na poziomie akademickim od 2003 roku jest realizowana na specjalnościach: zarządzanie bezpieczeństwem (na kierunku zarządzanie i marketing), administrowanie bezpieczeństwem (na kierunku administracja), bezpieczeństwo europejskie (na kierunku europeistyka), natomiast od 2006 roku Minister Nauki i Szkolnictwa Wyższego wprowadził nowe kierunki studiów, a następnie standardy kształcenia umożliwiające uczelniom publicznym kształcenie na studiach o charakterze stacjonarnym i niestacjonarnym na kierunkach związanych z bezpieczeństwem na studiach pierwszego i drugiego stopnia: bezpieczeństwo narodowe, bezpieczeństwo wewnętrzne, inżynieria bezpieczeństwa i ratownictwo medyczne, z uwzględnieniem szeregu specjalności, jak np. bezpieczeństwo publiczne, organizacja i funkcjonowanie służb mundurowych, kryminalistyka i techniki śledcze, zarządzanie kryzysowe itp., przy zachowaniu europejskich standardów zapewnienia jakości szkolnictwa wyższego, a więc uzgodnionego zestawu standardów, procedur i wskazówek 
(permanentnie aktualizowanych) dotyczących zapewnienia jakości kształcenia (Standardy..., 2005).

Na studiach pierwszego stopnia przygotowuje się studentów w zakresie wiedzy ogólnej z zakresu zagadnień społecznych i prawnych, tworzących podbudowę dla rozumienia istoty bezpieczeństwa w skali globalnej, państwowej, regionalnej i lokalnej, wiedzy z zakresu nauk społecznych, w tym tak fundamentalnych dla obywatela, jak prawa i wolności człowieka oraz zasady funkcjonowania państwa jego ustroju i struktury, podziału władzy w państwie oraz zadań i zasad funkcjonowania organów państwa, w tym usytuowania i roli administracji publicznej odpowiedzialnej za bezpieczeństwo wewnętrzne.

Powyższy zakres programowy pozwala absolwentowi zapoznać się z zagadnieniami związanymi z bezpieczeństwem wewnętrznym, a w szczególności regulacjami prawnymi w przedmiotowym zakresie, zasadami funkcjonowania instytucji państwowych, zadaniami administracji publicznej oraz problematyką zarządzania w sytuacjach kryzysowych, a także rozwiązywać proste problemy zawodowe oraz uczestniczyć w pracy zespołowej, w tym nabyć umiejętności kierowania małymi zespołami ludzkimi, komunikować się z otoczeniem oraz zbierać, hierarchizować, przetwarzać i przekazywać informacje. Poza tym studenci uczą się języka obcego na poziomie biegłości B2 Europejskiego Systemu Opisu Kształcenia Językowego Rady Europy.

Na studiach drugiego stopnia dotychczas zdobytą wiedzę pogłębia się o zagadnienia społecznopsychologiczne oraz umiejętności konfrontowania jej z elementami rzeczywistości wpływającymi na stan bezpieczeństwa wewnętrznego, umiejętności abstrakcyjnego pojmowania idei bezpieczeństwa oraz wyboru konkretnego i optymalnego w danych warunkach sposobu postępowania. Ponadto studenci kształceni są w zakresie uwzględniania ryzyka i przewidywania skutków podejmowanych decyzji, rozwiązywania złożonych problemów zawodowych, kierowania i kreatywnewgo uczestniczenia w pracy zespołowej oraz kierowania zespołami ludzkimi. Natomiast w celu pogłębienia i upraktycznienia wiedzy oraz doskonalenia nabywanych w trakcie nauki umiejętności studenci odbywają praktyki w instytucjach związanych z szeroko rozumianym bezpieczeństwem, a więc w wojsku, policji (i innych służbach mundurowych), jak też podmiotach funkcjonujących na zasadach komercyjnych.

Reasumując, tak skonstruowane ramowe treści kształcenia pierwszego i drugiego stopnia winny przygotować absolwenta do podjcia studiów trzeciego stopnia (doktoranckich), ewentualnie pracy zawodowej w administracji rządowej i samorządowej na stanowiskach związanych z obronnością, zarządzaniem kryzysowym i obroną cywilną. 
Wspomnieć jeszcze należy, że w systemie edukacji dla bezpieczeństwa, w ramach przygotowania do podjęcia pracy zawodowej w obronności i bezpieczeństwie w administracji rządowej i samorządowej oraz prywatnym sektorze ochrony, realizuje się także kształcenie pracowników ochrony osób i mienia oraz usług detektywistycznych w zakresach niezastrzeżonych dla organów i instytucji państwowych na mocy odrębnych przepisów (np. ustawy o policji) na poziomie szkół średnich oraz na studiach podyplomowych wyższych uczelni.

\section{ZAKOŃCZENIE}

W obowiązującym modelu edukacji dla bezpieczeństwa istotne znaczenie przypisać należy naukom o bezpieczeństwie, bowiem na nich ciąży główny ciężar poznania istoty bezpieczeństwa, a zatem wszelkiego rodzaju zagrożeń oraz przeciwdziałania im. Wymaga to szerokiego spektrum wiedzy z wielu dyscyplin naukowych, które pozwolą rozwijać zdolności, wspierać aktywizowanie i społeczne włączanie osób w system oraz rozwijanie zdolności specyficznych dla każdego człowieka.

Szeroki zakres wiedzy ze sfery bezpieczeństwa pozwala pracownikom służb mundurowych i sektora prywatnego funkcjonujących w bezpieczeństwie oraz społeczeństwa wykorzystać ją w maksymalnym stopniu, tak w pracy zawodowej, jak i życiu codziennym. Jak dowodzi praktyka, zakresu tej wiedzy nie należy utożsamiać z wiedzą ekspercką - taka wszechstronność byłaby z praktycznego punktu widzenia zbędna, a nawet niemożliwa. Wystarczy, aby zakres nabytej wiedzy ukształtował w świadomości tych podmiotów zaufanie do własnych kompetencji życiowych, tak o charakterze ogólnym, jak i zawodowym, oraz kompetencji kontroli zdarzeń i koordynacji różnych sfer życia. Dla właściwego postępowania wystarczająca jest zatem wiedza o szeroko rozumianym bezpieczeństwie, aspektach prawno-organizacyjnych tej sfery oraz innych nauk pokrewnych, jak i szeregu umiejętności niezbędnych do skutecznego radzenia sobie w codziennej egzystencji, a zatem znajomość zasad logicznego myślenia, niezbędną do prawidłowej analizy sytuacji, zdarzeń, informacji oraz formułowania na tej podstawie hipotez dotyczących zaistniałego zdarzenia, jak też umiejętność korzystania z wiedzy innych.

Edukacja dla bezpieczeństwa nie powinna mieć zatem jednorazowego charakteru, a polegać na systematycznym jej zgłębianiu i wynikających stąd możliwości w praktycznym zastosowaniu w życiu codziennym. 


\section{Bibliografia:}

Cieślarczyk, M. (2011). Teoretyczne i metodologiczne podstawy badania problemów bezpieczeństwa i obronności państwa. Siedlce: Wydawnictwo Uniwersytetu Przyrodniczo-Humanistycznego w Siedlcach.

Dębowiak, H. (2013). Jaka jest edukacja dla bezpieczeństwia w szkołach? W: M. Cieślarczyk, A. Filipek, A.W. Świderski, J. Ważniewska (red.), Elementy teorii i praktyki transdyscyplinarnych badań problemów bezpieczeństwa (s. 317-323). Siedlce: Wydawnictwo Uniwersytetu Przyrodniczo-Humanistycznego w Siedlcach.

Gąsiorowski, J. (2013). Kryminalistyka w naukach o bezpieczeństwie. W: M. Cieślarczyk, A. Filipek, A.W. Świderski, J. Ważniewska (red.), Elementy teorii i praktyki transdyscyplinarnych badań problemów bezpieczeństwa (s. 95-119). Siedlce: Wydawnictwo Uniwersytetu Przyrodniczo-Humanistycznego w Siedlcach.

Gąsiorowski, J. (2014). Nauki o bezpieczeństwie w systemie edukacji. W: W. Horyń, N. Dębowska (red.), Człowiek - Społeczeństwo - Państwo w sytuacjach kryzysu (s. 311-337). Poznań: Wydawnictwo Wyższej Szkoły Bezpieczeństwa w Poznaniu.

Głukowski, R. (2007). Rola i miejsce straży gminnych w systemie bezpieczeństwa państwa. W: K. Rajchel (red.), Przemiany i perspektywy straży miejskich i gminnych w ochronie bezpieczeństwa publicznego (s. 34-47). Warszawa: Przedsiębiorstwo Poligraficzno-Wydawnicze „GRAF” - Janusz Janiszewski w Warszawie.

Korzeniowski, L.F. (2012). Podstawy nauk o bezpieczeństwie. Warszawa: Wydawnictwo Difin SA.

Kunikowski J., Szmitkowski P. (2011). Problem zagrożeń w edukacji dla bezpieczeństwa. W: J. Kunikowski (red.), Uwarunkowania procesu edukacji dla bezpieczeństwa (s. 73-84). Siedlce: Wydawnictwo Uniwersytetu Przyrodniczo-Humanistycznego w Siedlcach.

Letkiewicz, A. (2009). Charakterystyka Policji. W: B. Wiśniewski, Z. Piątek (red.), Współczeny wymiar funkcjonowania Policji (s. 29-46). Warszawa: Wydawnictwo Akademii Obrony Narodowej.

Letkiwicz, A., Szankin, T. (2013). Organizacja i zarządzanie. Kompetencje menedżerskie w Policji, Szczytno: Wydawnictwo Wyższej Szkoły Policji w Szczytnie.

Michalak, P. (2005). Doskonalenie zawodowe - organizowanie i realizacja. Katowice: Wydawnictwo Szkoły Policji w Katowicach.

Standardy i wskazówki dotyczące zapewnienia jakości kształcenia w Europejskim Obszarze Szkolnictwa Wyższego (2005). Helsinki: Europejskie Stowarzyszenie na rzecz Zapewnienia Jakości w Szkolnictwie Wyższym.

Wierzbicki, G. (2011). Przygotowanie obronne społeczeństwa. Tradycje i współczesne ujęcie problematyki. W: J. Kunikowski (red.), Uwarunkowania procesu edukacji dla bezpieczeństwa (s. 27-72). Siedlce: Wydawnictwo Uniwersytetu Przyrodniczo-Humanistycznego w Siedlcach.

Ustawa z 2 kwietnia 1997 r. Konstytucja Rzeczypospolitej Polskiej (Dz.U. Nr 78 poz. 483 z późn. zm.).

Uchwała Centralnej Komisji do Spraw Stopni i Tytułów z 28 stycznia 2011 r. zmieniająca uchwałę w sprawie określenia dziedzin nauki i dziedzin sztuki oraz dyscyplin naukowych i artystycznych (M.P. z 2011 r. Nr 14 poz. 149). 
Ustawa z 7 września 1991 r. o systemie oświaty (Dz.U. z 2004 r. Nr 256 poz. 2572).

Ustawa z 27 lipca 2005 r. Prawo o szkolnictwie wyższym (Dz.U. z 2012 r. poz. 572 z późn. zm.).

Ustawa z 06 kwietnia 1990 r. o Policji (Dz.U. z 2015 r. poz. 355 z późn. zm.).

Program zatwierdzony do użytku szkolnego przez MEN 15 marca 1999 r., decyzja nr DKW - 4014-30/99.

Program zatwierdzony do użytku szkolnego przez MEN 15 marca 1999 r., decyzja nr DKW - 4014-121/99.

Rozporządzenie Rady Ministrów z 10 września 1990 r. w sprawie utworzenia Wyższej Szkoły Policji oraz zniesienia Akademii Spraw Wewnętrznych (Dz.U. Nr 64 poz. 373). Rozporządzenie Ministra Spraw Wewnętrznych i Administracji z 17 grudnia 2009 r. sprawie szkolenia podstawowego strażników gminnych (miejskich) (Dz.U. z 2013 r. poz. 353). 